\title{
Gastrointestinal parasite infection intensity and hematological parameters in South African communal indigenous goats in relation to anemia
}

\author{
Takalani Judas Mpofu(D, Khathutshelo Agree Nephawe(D) and Bohani Mtileni(D) \\ Department of Animal Sciences, Tshwane University of Technology, Pretoria, South Africa. \\ Corresponding author: Takalani Judas Mpofu, e-mail: mpofutj@tut.ac.za \\ Co-authors: KAN: nephaweka@tut.ac.za, BM: mtilenib@tut.ac.za \\ Received: 25-04-2020, Accepted: 18-09-2020, Published online: 27-10-2020
}

doi: www.doi.org/10.14202/vetworld.2020.2226-2233 How to cite this article: Mpofu TJ, Nephawe KA, Mtileni B (2020) Gastrointestinal parasite infection intensity and hematological parameters in South African communal indigenous goats in relation to anemia, Veterinary World, 13(10):2226-2233.

\begin{abstract}
Aim: The study was conducted to determine the intensity of gastrointestinal parasite (GIP) infections and hematological parameters in South African communal indigenous goats in relation to anemia.

Materials and Methods: A total of 288 goats were randomly sampled in areas representing four agro-ecological zones. Fecal and blood samples were collected from the rectum and jugular vein, respectively, of each animal. The number of eggs per gram (EPG) and oocysts per gram (OPG) of feces and the hematological parameters were determined using the modified McMaster technique and a BC-2800Vet ${ }^{\circledR}$ automatic hematology analyzer, respectively. Data were analyzed using the repeated measures techniques of Minitab 17, modeling the covariance structure of the observed data.

Results: Based on EPG and OPG, goats in humid zone were significantly infected $(\mathrm{p}<0.05)$ with strongyles, Eimeria, Moniezia, and Trichuris spp. Hematological parameters of goats in arid and humid zone were lower $(\mathrm{p}<0.05)$ than those in semi-arid and dry sub-humid zone. GIP infection intensities were higher $(\mathrm{p}<0.05)$ in young animals than in adult and suckling goats. GIP infection intensity was similar between goat sexes, while hematological parameters were higher $(\mathrm{p}<0.05)$ in females. Higher $(\mathrm{p}<0.05)$ infection intensities for strongyles $(302.90 \mathrm{EPG})$ and Eimeria $(216.09$ EPG) were observed in winter compared to summer (strongyles: 302.90, Eimeria: $216.09 \mathrm{EPG})$. Higher $(\mathrm{p}<0.05)$ values for the hematological parameters were observed during summer compared to that in winter.
\end{abstract}

Conclusion: GIP infection intensity in the winter could be associated with hypochromic and normocytic anemia which likely to affects suckling goats while in the summer could be associated with normochromic and normocytic anemia which likely to affect young goats.

Keywords: hemoglobin concentration, mean corpuscular hemoglobin, packed cell volume, strongyles.

\section{Introduction}

Domestic goats (Capra hircus) play an important role in meeting the nutritional, economic, and social needs of many rural households $[1,2]$. The global demand for sources of animal protein is growing $[3,4]$ and it is obvious that the livestock industry, especially goat production, will need to be expanded. However, goats are highly susceptible to gastrointestinal parasite (GIP) infections [5-7], which imposes serious productivity constraints in marginal systems, resulting in clinical diseases, loss of productivity [8,9], and death [10]. GIP control methods previously proposed include chemical treatment, husbandry management, or biological approaches [11]. Of the approaches, chemotherapy (anthelmintic drugs) has been the most widely used method; however, this

Copyright: Mpofu, et al. Open Access. This article is distributed under the terms of the Creative Commons Attribution 4.0 International License (http://creativecommons.org/licenses/by/4.0/), which permits unrestricted use, distribution, and reproduction in any medium, provided you give appropriate credit to the original author(s) and the source, provide a link to the Creative Commons license, and indicate if changes were made. The Creative Commons Public Domain Dedication waiver (http://creativecommons.org/ publicdomain/zero/1.0/) applies to the data made available in this article, unless otherwise stated. noticeably has often been associated with cases of drug-resistant parasites [12-14] and drug residues in the end-product food and the environment [15]. The presence and prevalence of GIPs in goats have been well documented in several studies, including goats of South Africa [7,16,17] and other African countries such as Nigeria [18], Egypt [19], Ethiopia [20], Cameroon [21], Ghana [22], and Zimbabwe [23].

Some GIPs suck blood (especially strongyles) and where there is a heavy parasitic burden, they may cause anemia [24] as well as other hematological and biochemical disturbances $[25,26]$. Anemia is not a disease entity, but rather is functionally defined as decreased oxygen-carrying capability of blood [27]. Clinically, anemia is characterized by an absolute decrease in the packed cell volume (PCV), hemoglobin concentration $(\mathrm{Hgb})$ [28], and total erythrocyte count per unit volume of blood with values below the normal generally observed in hydrated animals [29]. $\mathrm{PCV}, \mathrm{Hgb}$, and mean corpuscular hemoglobin $(\mathrm{MCH})$ are major indices used in the diagnosis of anemia [30]. Typically, PCV values in goats ranges between $22 \%$ and $38 \%$ [31,32], whereas the $\mathrm{Hgb}$ and $\mathrm{MCH}$ range 8-18 pg/dL and 5.2-8 pg, respectively [32]. Animals 
with lower hematological values are considered anemic [30,33]. Animals with good blood composition are likely to show good production performance [34]. Hematological studies are of ecological and physiological interest to understand the relationship of blood characteristics to the environment [35] and to certain diseases $[34,36]$. Of noteworthy, hematological parameters are dependent on the environment and condition of the animal, such as infection status, breed, age, and other factors. In South Africa, there is a wide range of environments [37,38] with arid and semi-arid agro-ecological zones (AEZs) occupying the largest percentage of land surface area. However, there is currently a paucity of published information available on the intensity of GIPs in South African communal indigenous goats in different AEZs.

The current research was, therefore, conducted to determine the intensity of the GIP infections and the hematological parameters in South African communal indigenous goats in relation to anemia.

\section{Materials and Methods}

\section{Ethical approval}

The study was approved by the Animal Research Ethics Committee of the Faculty of Science, Tshwane University of Technology(FCRE 2017/10/01 [02] $[\mathrm{SCI}])$. Ethical concerns were addressed by adhering to local animal welfare regulations and practices and by conforming to the ethical guidelines of Tshwane University of Technology for animal use in research.

\section{Study site and animal management}

A longitudinal study was conducted in four different AEZs of South Africa: Arid, semi-arid, humid, and dry sub-humid zones. The selected AEZs varied in rainfall distribution and in the percentage of land coverage (Table-1) [38-40]. A total of 288 communal indigenous goats (101 males and 187 females) were randomly sampled during the summer (NovemberDecember 2017) and winter (June-July 2018) in areas representing four $A E Z s$ : Arid $=80$; semi-arid $=76$; humid $=62$, and dry sub-humid $=70$. The sample size was determined using Equation 1 [41].

$$
n=\frac{1.96^{2} p q}{L^{2}}
$$

where $n=$ sample size, $p=$ expected prevalence, $q=1-p$, and $L=$ limits of error on the prevalence. Because the prevalence in the local goat population was unknown, a hypothesized prevalence of $75 \%$ was used with a $5 \%$ limit of error of the prevalence. Based on these assumptions, the required sample size was calculated to be 288 goats for each set of the seasons. The animals were maintained under extensive grazing systems in which during the day they were released to graze on communal lands and corralled at night. The flocks were classified by age (adult: $\geq 3$ years, young goat: 1-2 years, and suckling kids: $<1$ year), as described by Kheirandish et al. [42]. Plastic ear tags (Allflex ${ }^{\circledR}$ - Somerset West, Western Cape, South
Africa) bearing individual identification numbers were placed on the right ear of each animal during the initial sample collection to allow for repeated sampling of the same animals over the study period.

\section{Sample collection and analysis}

Approximately $10 \mathrm{~g}$ of fecal material and $10 \mathrm{ml}$ of blood were collected from the rectum and the jugular vein, respectively, of the animals. The samples were collected twice during each season from each of the animals. Fecal samples were placed into airtight containers and labeled while the blood samples were collected by venipuncture into EDTA Vacuette ${ }^{\circledR}$ (Greiner Bio-One, Austria) tubes and labeled. All samples were maintained at $2-4^{\circ} \mathrm{C}$ in cooler boxes and transported to the laboratory for coprological and hematological examination within $24 \mathrm{~h}$. The fecal samples were subjected to quantitative examination for GIP eggs and oocysts. The eggs per gram (EPG) and oocysts per gram (OPG) counts were determined using a modified McMaster technique as described by Hansen and Perry [43]. For positive fecal samples, slides were prepared for examination under the microscope (10× magnification). The egg floatation fluid used was $\mathrm{NaCl}(\mathrm{NaCl}, 500 \mathrm{~g}$; water, $1000 \mathrm{~mL}$ ) into a routine fecal floatation test kit (Ovatector ${ }^{\circledR}$ Kyron Laboratories [Pty] Ltd, South Africa). To prevent bubbles when counting the eggs and oocysts, the fecal samples were ground in five drops of Bloat Guard. Each fecal count was multiplied by 100 to estimate the number of eggs in the entire animal system [44]. The GIPs eggs were identified under a compound microscope $(10 \times)$ based on morphological appearance and the size of the helminth eggs, protozoa cysts, and trophozoites [45,46]. Distinguishable nematodes (Trichuris spp. and Strongyloides papillosus), trematodes, and cestode eggs were directly identified. A sample was considered positive when a minimum of one GIP egg was detected under the microscope. Fecal cultures were prepared by incubating 2-3 $\mathrm{g}$ of feces at $26-28^{\circ} \mathrm{C}$ for 7 days with $80 \%$ humidity after which time the infecting larvae were collected using a modified Baermann technique. $\mathrm{L}_{3}$-stage nematodes were identified according to the protocol proposed by Van Wyk et al. [47]. Eimeria species were identified following oocyst sporulation within the feces after incubation for 7 days at $26-28^{\circ} \mathrm{C}$ in a thin layer of $2.5 \%$ potassium dichromate. Identification of the Eimeria species was based on morphological characteristics of the oocysts (size, shape, color, and presence or absence of a micropyle and its cap). The hematological parameters evaluated included PCV (\%), $\mathrm{Hgb}(\mathrm{g} / \mathrm{dL})$, and $\mathrm{MCH}(\mathrm{pg})$, which were analyzed using a BC-2800Vet ${ }^{\circledR}$ Auto Hematology Analyzer (Shenzhen Mindray BioMedical Electronics Co., Ltd, Hamburg, Germany).

\section{Statistical analysis}

The EPG and OPG values for all the detected GIPs were transformed through a base 10 logarithm 
$\left[\log _{10}\right.$ Fecal Egg Count $($ FEC $\left.)+25\right]$ to approximate a normal distribution. The transformed data were used for statistical analysis. The infection intensity and hematological parameters data were analyzed using the repeated measured techniques of the Minitab [48] in PROC MIXED considering the covariance structure of the observed data. The FEC-transformed data and the results were then back-transformed by taking the anti-logarithms and the results were presented as geometric means. The means were separated using Fisher's protected least significant difference test $(\mathrm{p}<0.05)$. The following statistical model was used (Equation 2).

$$
Y_{i j k l m}=\mu+T_{i}+\varepsilon_{i j}+W_{k}+S_{l}+D_{m}+\varepsilon_{i j k l m}
$$

Where $Y_{\mathrm{ijkl}}=$ measurement of response (individual GIP species FEC, hemoglobin, PCV, and $\mathrm{MCH}$ ) on the $j^{\text {th }}$ animal, $\mu=$ overall mean, $T=$ fixed effect of AEZ (arid, semi-arid, dry sub-humid and humid), $W_{k}=$ fixed effect of the $k^{\text {th }}$ season on measurements ( $k=$ summer and winter), $S_{l}=$ fixed effect of the $l^{\text {th }}$ sex on measurements $(l=$ male and female), $D_{m}=$ fixed effect of the $m^{\text {th }}$ age on measurements ( $m=$ suckling, young and adult goat), $\varepsilon_{i j}=$ random effect associated with the $j^{\text {th }}$ animal on the $i^{\text {th }}$ AEZ, $\varepsilon_{i j k l m}=$ random error associated with the $j^{\text {th }}$ goat of a $l^{\text {th }}$ sex and $m^{\text {th }}$ age at the $k^{\text {th }}$ season in the $i^{\text {th }} \mathrm{AEZ}$.

\section{Results}

The $\mathrm{L}_{3}$ nematodes identified in the fecal cultures for all the animals in arid, semi-arid, and humid zones were Haemonchus spp., S. papillosus, and Oesophagostomum spp. In the dry sub-humid zone, Haemonchus and $S$. papillosus were the $\mathrm{L}_{3}$ nematodes that were identified. Regarding Eimeria species, E. arloingi, E. christenseni, E. alijevi, E. jolchijevi, $E$. caprina, E. caprovina, and $E$. hirci were identified in fecal cultures from all AEZs. Five species of GIP eggs and oocysts observed were Moniezia, S. papillosus, Trichuris, Eimeria spp., and strongyles with mean EPG counts of 179.53, 182.70, 195.00, 201.69, and 274.45, respectively (Table-2). The mean $\mathrm{MCH}, \mathrm{Hgb}$, and PCV for South African communal indigenous goats in the present study were $4.97 \mathrm{pg}, 8.71 \mathrm{~g} / \mathrm{dl}$, and $27.03 \%$, respectively. The AEZ significantly influenced the intensity of all the GIP infections and hematological blood parameters $(\mathrm{p}<0.05)$. The infection intensities of strongyles (323.50EPG), Eimeria (263.60OPG), Moniezia spp. (194.04OPG), and Trichuris spp. (236.00EPG) were significantly higher in the humid-zone goat populations compared to that in other zones $(p<0.05)$. Based on EPG and OPG values, lower infection intensities of the GIPs understudy

Table-1: Agro-ecological zones and their features in South Africa.

\begin{tabular}{|c|c|c|c|c|c|c|c|}
\hline $\begin{array}{l}\text { Agro-ecological } \\
\text { zone }\end{array}$ & $\begin{array}{l}\text { Annual } \\
\text { rainfall } \\
(\mathrm{mm})\end{array}$ & $\begin{array}{l}\text { Length of } \\
\text { growing } \\
\text { period (d) }\end{array}$ & $\begin{array}{l}\text { Aridity index* } \\
\text { (P/Ep) }\end{array}$ & $\begin{array}{c}\text { Percentage } \\
\text { of land } \\
\text { surface }\end{array}$ & $\begin{array}{l}\text { Vegetation } \\
\text { type }\end{array}$ & \% Rangeland & $\%$ Cultivated \\
\hline Desert & $<200$ & & & 22.8 & & & \\
\hline Arid & $201-400$ & $<90$ & $<0.39$ & 24.6 & $\begin{array}{l}\text { Annual } \\
\text { grassland }\end{array}$ & 87 & 7 \\
\hline Semi-arid & $401-600$ & $90-179$ & $0.40-0.79$ & 24.6 & $\begin{array}{l}\text { Thorny } \\
\text { savannahs }\end{array}$ & 54 & 35 \\
\hline Dry sub-humid & $601-800$ & $180-269$ & $0.80-0.11$ & 18.5 & $\begin{array}{l}\text { Broad-leaved } \\
\text { savannah } \\
\text { woodlands }\end{array}$ & 34 & 47 \\
\hline Humid & $801-1000$ & $270-365$ & $>0.12$ & 6.7 & $\begin{array}{l}\text { Rain forest and } \\
\text { savannahs }\end{array}$ & & \\
\hline Super humid & $>1000$ & & & 2.8 & & & \\
\hline
\end{tabular}

*The ratio of precipitation to potential evapo-transpiration; Adapted from Schulze [38]; Mpofu et al. [39]; UN, Environment Management Group [40]

Table-2: Mean number of gastrointestinal parasite eggs per gram ( $\pm \mathrm{SE}$ ) of fecal material and hematological parameters for goats in different agro-ecological zones of South Africa.

\begin{tabular}{|c|c|c|c|c|c|}
\hline \multirow[t]{2}{*}{ Parameters } & \multicolumn{4}{|c|}{ Agro-ecological zones } & \multirow[t]{2}{*}{ Mean } \\
\hline & Arid & Semi-arid & Dry sub-humid & Humid & \\
\hline \multicolumn{6}{|l|}{ Gastrointestinal parasites } \\
\hline Eimeria spp. & $169.96^{\complement} \pm 10.7$ & $167.29^{\complement} \pm 10.9$ & $205.89^{b} \pm 11.3$ & $263.60^{\mathrm{a}} \pm 12.2$ & 201.69 \\
\hline Trichuris spp. & $180.49^{b, c} \pm 10.5$ & $165.73^{c} \pm 10.7$ & $197.76^{b} \pm 11.1$ & $261.00^{\mathrm{a}} \pm 11.9$ & 195.00 \\
\hline Strongyloides papillosus & $151.01^{\mathrm{c}} \pm 10.9$ & $195.60^{\mathrm{a}, \mathrm{b}} \pm 11.10$ & $211.70^{\mathrm{a}} \pm 11.40$ & $172.50^{\mathrm{b}, \mathrm{c}} \pm 12.30$ & 182.70 \\
\hline Moniezia spp. & $158.11^{\mathrm{b}} \pm 7.83$ & $208.83^{a} \pm 7.98$ & $157.12^{\mathrm{b}} \pm 8.23$ & $194.04^{a} \pm 8.86$ & 179.53 \\
\hline Strongyles & $218.71^{\mathrm{c}} \pm 14.0$ & $275.00^{\mathrm{b}} \pm 14.3$ & $280.60^{b} \pm 14.8$ & $323.50^{a} \pm 15.9$ & 274.45 \\
\hline Mean FEC & 181.65 & 178.72 & 227.66 & 233.83 & \\
\hline \multicolumn{6}{|l|}{ Hematological parameters } \\
\hline Hemoglobin $(\mathrm{g} / \mathrm{dl})$ & $8.19^{b} \pm 0.21$ & $9.17^{\mathrm{a}} \pm 0.21$ & $9.36^{a} \pm 0.22$ & $8.12^{b} \pm 0.23$ & 8.71 \\
\hline PCV $(\%)$ & $25.84^{b} \pm 0.47$ & $28.00 \pm 12^{\mathrm{a}} \pm 0.48$ & $28.54^{a} \pm 0.50$ & $25.63^{b} \pm 0.54$ & 27.03 \\
\hline $\mathrm{MCH}(\mathrm{pg})$ & $4.28^{b} \pm 0.20$ & $5.47^{a} \pm 0.20$ & $5.60^{\mathrm{a}} \pm 0.21$ & $4.53^{b} \pm 0.23$ & 4.97 \\
\hline
\end{tabular}

$a, b, c$ Row means with different superscripts differs significantly $(p<0.05)$; FEC=Fecal egg count, PCV=Packed cell volume, $\mathrm{MCH}=$ Mean corpuscular hemoglobin 
were observed in arid (strongyles, 218.70; S. papillosus, 151.01; Moniezia spp., 158.11; and Trichuris, 180.49EPG) and semi-arid (Eimeria, 167.29OPG) zones. For hematological parameters, $\mathrm{Hgb}, \mathrm{PCV}$, and $\mathrm{MCHC}$ of goats in arid zones $(\mathrm{Hgb}, 8.19 \mathrm{~g} / \mathrm{dl}$; PCV, 25.84\%; and $\mathrm{MCH}, 4.28 \mathrm{pg}$ ) and humid zones ( $\mathrm{Hgb}$, 8.12; PCV, 25.63; $\mathrm{MCH}, 4.53 \mathrm{pg}$ ) were significantly lower $(\mathrm{p}<0.05)$ compared to those in semi-arid zones (Hgb, $9.17 \mathrm{~g} / \mathrm{dl} ; \mathrm{PCV}, 28.12 \%$; and $\mathrm{MCH}, 5.47 \mathrm{pg}$ ) and dry sub-humid zones (Hgb, $9.36 \mathrm{~g} / \mathrm{dl}$; PCV, 28.54\%; and $\mathrm{MCH}, 5.60 \mathrm{pg}$ ).

The GIP infection intensity was significantly higher $(\mathrm{p}<0.05)$ in young animals (strongyles, 455.2; S. papillosus, 317.9; Eimeria, 330.3; Moniezia spp., 325.10; and Trichuris, 315.62EPG) compared to that in suckling kids (strongyles, 86.10; S. papillosus, 39.50; Eimeria, 80.30; Moniezia spp., 36.70; and Trichuris, 71.04EPG) and adult goats (strongyles, 282.04EPG; Eimeria, 194.51; and Moniezia spp., 176.77OPG) (Table-3). The infection intensity was similar for $S$. papillosus (317.90 vs. 190.83) in young and adult goats $(\mathrm{p}>0.05)$; however, the adult and suckling goats were also similarly infected with Eimeria (194.51 vs. 80.30OPG). For hematological parameters, $\mathrm{Hgb}, \mathrm{PCV}$, and $\mathrm{MCH}$ were significantly different $(\mathrm{p}<0.05)$ for goat ages, with the highest mean values being recorded in adult goats $(\mathrm{Hgb}, 9.66 \mathrm{~g} / \mathrm{dl}$; PCV, 29.27\%; and MCH, $5.82 \mathrm{pg}$ ), followed by young goats (Hgb, $8.71 \mathrm{~g} / \mathrm{dl}$; PCV, 27.02\%; and $\mathrm{MCH}, 5.08$ $\mathrm{pg}$ ), and lastly by suckling kids (Hgb, $7.76 \mathrm{~g} / \mathrm{dl}$; PCV, 24.87\%; and $\mathrm{MCH}, 4.02 \mathrm{pg}$ ).

The infection intensity of the Eimeria and strongyles was significantly influenced by season $(p<0.05)$, but the influence of season on infection intensity of $S$. papillosus, Moniezia, and Trichuris spp. was insignificant ( $>0.05)$ (Table-4). Significantly higher infection intensities were observed for strongyles (302.90EPG) and Eimeria (216.09OPG) during winter season compared to that in summer season $(\mathrm{p}<0.05)$, whereas, the S. papillosus, Moniezia, and Trichuris spp. infection intensities were similar between seasons $(p>0.05)$. There was a significant effect of season on hematological blood parameters $(p<0.05)$ with higher values being observed during the summer season ( $\mathrm{Hgb}$, $10.08 \mathrm{~g} / \mathrm{dl}$; PCV, 28.52\%; and MCH, $5.47 \mathrm{pg}$ ) compared to that in the winter season $(\mathrm{Hgb}, 7.34 \mathrm{~g} / \mathrm{dl}$; $\mathrm{PCV}, 25.52 \%$; and $\mathrm{MCH}, 4.47 \mathrm{pg}$ ).

There was no significant influence from the sex of the goats on any of the GIP infections ( $p>0.05)$, except for Moniezia spp. for which higher infection intensity

Table-3: Mean gastrointestinal parasite eggs per gram ( $\pm \mathrm{SE})$ of fecal material and hematological parameters between goats of different ages.

\begin{tabular}{lccc}
\hline Parameters & \multicolumn{3}{c}{ Goat ages } \\
\cline { 2 - 4 } & Suckling & Young & Adult \\
\hline Gastrointestinal parasites & & & \\
Eimeria spp. & $80.30^{\mathrm{b}} \pm 13.6$ & $330.30^{\mathrm{a}} \pm 12.2$ & $194.51^{\mathrm{b}} \pm 7.07$ \\
Trichuris spp. & $71.04^{\mathrm{c}} \pm 13.3$ & $315.62^{\mathrm{a}} \pm 11.9$ & $196.84^{\mathrm{b}} \pm 6.94$ \\
Strongyloides papillosus & $39.50^{\mathrm{c}} \pm 13.7$ & $317.9^{\mathrm{a}} \pm 12.30$ & $190.83^{\mathrm{a}} \pm 7.16$ \\
Moniezia spp. & $36.70^{\mathrm{c}} \pm 9.90$ & $325.10^{\mathrm{a}} \pm 8.87$ & $176.77^{\mathrm{b}} \pm 5.15$ \\
Strongyles & $86.10^{\mathrm{c}} \pm 17.8$ & $455.2^{\mathrm{a}} \pm 15.9$ & $282 . \pm 04^{\mathrm{b}} \pm 9.24$ \\
Mean FEC & 62.73 & 348.82 & 208.20 \\
Hematological parameters & & & $9.71^{\mathrm{b}} \pm 0.23$ \\
Hemoglobin (g/dl) & $7.76^{\mathrm{c}} \pm 0.26$ & $27.02^{\mathrm{b}} \pm 0.54$ & $9.66^{\mathrm{a}} \pm 0.14$ \\
PCV (\%) & $24.87^{\mathrm{c}} \pm 0.60$ & $5.08^{\mathrm{b}} \pm 0.23$ & $29.26^{\mathrm{a}} \pm 0.31$ \\
MCH (pg) & $4.02^{\mathrm{c}} \pm 0.25$ & $5.82^{\mathrm{a}} \pm 0.13$ \\
\hline
\end{tabular}

$a, b, c$ Row means with different superscripts differs significantly $(p<0.05)$; FEC=Fecal egg count; PCV=Packed cell volume, $\mathrm{MCH}=$ Mean corpuscular hemoglobin

Table-4: Mean gastrointestinal parasite eggs per gram $( \pm S E)$ of fecal material and goat hematological parameters in different seasons and goat sexes.

\begin{tabular}{|c|c|c|c|c|}
\hline \multirow[t]{2}{*}{ Parameters } & \multicolumn{2}{|c|}{ Season } & \multicolumn{2}{|c|}{ Sex } \\
\hline & Winter & Summer & Female & Male \\
\hline \multicolumn{5}{|l|}{ Gastrointestinal parasites } \\
\hline Eimeria spp. & $216.09^{\mathrm{a}} \pm 8.39$ & $187.27^{b} \pm 8.39$ & $201.34^{\mathrm{a}} \pm 8.14$ & $202.03^{\mathrm{a}} \pm 9.19$ \\
\hline Trichuris spp. & $203.35^{\mathrm{a}} \pm 8.23$ & $185.64^{\mathrm{a}} \pm 8.23$ & $186.45^{\mathrm{a}} \pm 7.99$ & $202.54^{\mathrm{a}} \pm 9.02$ \\
\hline Strongyloides papillosus & $192.29^{\mathrm{a}} \pm 8.49$ & $173.19^{\mathrm{a}} \pm 8.49$ & $174.35^{\mathrm{a}} \pm 8.24$ & $191.13^{\mathrm{a}} \pm 9.30$ \\
\hline Moniezia spp. & $185.95^{\mathrm{a}} \pm 6.11$ & $173.10^{\mathrm{a}} \pm 6.11$ & $258.58^{a} \pm 5.93$ & $100.47^{b} \pm 6.70$ \\
\hline Strongyles & $302.90^{\mathrm{a}} \pm 11.0$ & $246.00^{\mathrm{b}} \pm 11.0$ & $260.50^{a} \pm 10.6$ & $266.40^{\mathrm{a}} \pm 12.0$ \\
\hline Mean FEC & 220.11 & 193.04 & 202.24 & 206.57 \\
\hline \multicolumn{5}{|l|}{ Hematological parameters } \\
\hline Hemoglobin (g/dl) & $7.34^{b} \pm 0.16$ & $10.08^{\mathrm{a}} \pm 0.16$ & $9.33^{a} \pm 0.16$ & $8.09^{b} \pm 0.18$ \\
\hline PCV (\%) & $25.58^{\mathrm{b}} \pm 0.37$ & $28.52^{\mathrm{a}} \pm 0.37$ & $28.50^{\mathrm{a}} \pm 0.36$ & $25.60^{\mathrm{b}} \pm 0.41$ \\
\hline $\mathrm{MCH}(\mathrm{pg})$ & $4.47^{b} \pm 0.16$ & $5.47^{a} \pm 0.16$ & $5.62^{\mathrm{a}} \pm 0.15$ & $4.32^{b} \pm 0.17$ \\
\hline
\end{tabular}

$a, b, c$ Row means with different superscripts differs significantly $(p<0.05)$; FEC $=$ Fecal egg count, PCV $=$ Packed cell volume, $\mathrm{MCH}=$ Mean corpuscular hemoglobin 
values were observed in female goats (258.58) compared to those in male goats (100.47OPG). The hematological parameters were significantly higher $(\mathrm{p}<0.05)$ in female goats $(\mathrm{Hgb}, 9.33 \mathrm{~g} / \mathrm{dl}$; PCV, 28.50\%; and $\mathrm{MCH}, 5.62 \mathrm{pg}$ ) compared to that in male goats (Hgb, $8.09 \mathrm{~g} / \mathrm{dl}$; PCV, 25.60\%; and MCH, $4.32 \mathrm{pg}$ ).

\section{Discussion}

In this paper, and to be consistent with epidemiological terminologies, the intensity of the infection is defined as the mean number of EPG or OPG of feces calculated over all samples tested positive for the parasite, intensity is zero when a host has no GIP $[49,50]$; this contrasts with the definition suggested by Bush et al. [51]. Anemia can be classified according to cell size (normocytic, microcytic, or macrocytic, indicating normal, increased, or decreased PCV, respectively) and to Hgb concentration (normochromic, hypochromic, or hyperchromic, indicating normal, decreased, or increased $\mathrm{Hgb}$ concentration, respectively) $[52,53]$.

The findings that infection intensity for all GIPs and hematological parameters significantly differed with AEZ $(p<0.05)$ may be attributed to differences in AEZ's climatic factors, such as temperature, rainfall pattern, aridity index, and humidity, which are known to influence infection intensity and the development of nematode eggs $[23,54,55]$. Higher infection intensity for all of the GIPs, except for S. papillosus in humid zones, may be associated to the fact that the humid areas experience warm temperatures and high rainfall (801-1000 mm annually), which are capable of sustaining plant life for 270-365 plant growing days $[38,56]$. This, in turn, provides a favorable environment for pre-parasitic nematodes development, survival, and transmission $[43,54]$.

The higher infection intensity of Moniezia spp. observed in semi-arid goat populations could be attributed to shorter rainy seasons and higher temperatures [38,57], which may be conducive for Moniezia spp. development or to increased availability of intermediate parasite hosts in the vicinity [58]. The lower infection intensity observed for strongyles, S. papillosus, Moniezia, Eimeria, and Trichuris spp. in arid zone may have been attributed to warmer temperatures and low erratic rainfall levels [38,57], which are unfavorable for the GIP development, survival, and transmission $[43,56]$. However, in contrast to our current findings, a lack of variation in GIP infection intensity across different locations has also been reported $[54,58]$.

Lower hematological parameters for goats in humid zones could be associated with the high infection intensities of GIPs in those areas. These results are in agreement with several previous reports that low $\mathrm{PCV}[59,60], \mathrm{Hgb}$ [61], and $\mathrm{MCH}$ [30] values are commonly associated with high FEC, attributed to the adult parasites sucking a substantial amount of blood from the abomasum of infected animal. Despite lower GIP infection intensity in arid goat population, noteworthy, the lower hematological parameters observed in this goat population may have been resulted from the nutritional stress associated with these areas as they are characterized by warm temperatures, low erratic rainfall distribution [56], and fluctuations in forage quality and quantity. Nutritional stress is known to lower the hematological parameters of animals [62-64]. The higher hematological parameters for goat populations in the semi-arid and dry sub-humid zones can be a result of lower GIP infection intensity. For the goats in the AEZs evaluated in the current study, infection intensity and hematological parameters (PCV and $\mathrm{Hgb}$ ) suggested that GIP infections resulted to normocytic and normochromic anemia, indicating normal values for $\mathrm{PCV}$ and $\mathrm{Hgb}$ concentration.

Infection intensity revealed significant differences between age groups $(p<0.05)$, with young animals having higher EPG or OPG compared to that of adult and suckling animals. These findings are in agreement with the previous reports where young animals tend to be more susceptible to infections $[23,65,66]$. The increased susceptibility of young animals may be due to immunological immaturity and immunological unresponsiveness [67]. In contrast, adult animals may acquire immunity to parasites through frequent challenges and thereby expel ingested parasites before an infection is established [68]. Contrary to our current findings that suckling and adult goats were equally infected with Eimeria (p>0.05), Verma et al. [57] reported that goats between 1 and 6 months of age (suckling kids) are heavily infected with Eimeria compared to those of goats older than 12 months of age (adults). The observed difference in suckling, young, and adult South African communal indigenous goats suggests that the oxygen-carrying capacity of the blood was higher in adult goats, which can be supported by the fact that immunological maturity is acquired with increasing age after repeated exposure [57]. Suckling animals have lower PCV, Hgb, and $\mathrm{MCH}$ in comparison with adult animals [69]. It may be postulated that GIP infection intensity resulted in hypochromic and normocytic anemia in suckling goats, while normochromic and normocytic anemia resulted in young and adult goats.

The effect of the sex of animals was not significant ( $>0.05$ ) except for the infection intensity of Moniezia spp., where mean OPG value was significantly higher in females compared to that in males $(p<0.05)$. A lack of significant effect of the sex of animals on infection intensity for several GIPs had also been previously reported [57] and may have been attributed to the fact that both male and female goats are exposed to similar environmental conditions that are conducive for GIP infection. However, the current findings are in contrast with some other reports that claim the sex of the animals have a significant association with the infection intensity of GIP [19]. Ayaz et al. [66] reported that the intensity of infection is higher in male animals compared to that in 
female animals, while Sharma et al. [65] reported higher infection intensity in females compared to that in males. Specifically, high Moniezia spp. infection intensities in females might be due to stress and low immune status during pregnancy, parturient paresis, or lactation periods [55]. The findings that hematological parameters were significantly higher in females may be attributed to the fact that females are more resistant to GIP [69]. The GIP infection intensity across the sex of the goat resulted in normochromic and normocytic anemia.

The findings that animals during the winter season were more heavily infected with Eimeria and strongyles compared to that in the summer season was noteworthy since one could anticipate that Eimeria arthropod intermediate hosts would favor a moist microclimate in the pasture. Higher GIP infection intensity in wet months (summer season) compared to winter months has been reported by various researchers $[65,70]$ and is attributed to the differences in the humidity and temperature during summer season, which is favorable for the development, hatching, survival, and translocation of pre-parasitic stages. This might result in higher infection intensities during the summer season. However, reduced grazing hours also reduces the chances of contact between hosts and parasites, leading to lower infection intensities in winter season. Inclement environmental conditions in winter season force strongyles to go under hypobiosis, resulting in a reduction in the number of eggs [57]. The higher hematological parameters observed during summer may have been due to the lower infection intensities of Eimeria and strongyles, while the lower hematological parameters observed during winter may also have been associated with higher infection intensities of Eimeria and strongyles in the same season. Higher infection intensities of strongyles lead to the lower PCV and Hgb concentrations in animals [71]. The GIP infection intensities in winter resulted in hypochromic and normocytic anemia, which may have resulted from higher infection intensities by strongyles and Eimeria, while in the summer season the GIP infection intensities resulted in normochromic and normocytic anemia.

\section{Conclusion}

GIP infection intensity varies with AEZs and the age of goat, and, may affect the health status and productivity of goats. The results from the current study suggest that the GIP infection intensity in the winter season resulted in hypochromic and normocytic anemia, whereas in the summer season and across the sex of goat resulted in normocytic and normochromic anemia. These hematological parameters can be used as indicators of anemia resulted from the GIP infections in goat. Further studies are recommended to investigate the genetic resistance against GIP in South African communal indigenous goats using the intensity of infection and hematological parameters as phenotypic indicators.

\section{Authors' Contributions}

This study is the component of the work toward the Ph.D. thesis of the first author TJM, under the guidance of KAN and BM. TJM designed the study, participated in all experiments, coordinated the data analysis and wrote the manuscript. KAN and BM designed the study, coordinated all the work and revised the manuscript. All authors read and approved the final manuscript.

\section{Acknowledgments}

The authors are grateful to the communal goat farmers and veterinary officers in Kwa-Zulu Natal, Limpopo, and Mpumalanga Provinces for their assistance and participation in this study. This work was partially supported by the Tshwane University of Technology Postgraduate Scholarship, and the National Research Foundation, South Africa (Grants: 112055, 121138 and KIC: 115724) and Erasmus+ $(65 / 2020 I)$.

\section{Competing Interests}

The authors declare that they have no competing interests.

\section{Publisher's Note}

Veterinary World remains neutral with regard to jurisdictional claims in published institutional affiliation.

\section{References}

1. Byaruhanga, C., Oluka, J. and Olinga, S. (2015) Socioeconomic aspects of goat production in a rural agro-pastoral system of Uganda. Univ. J. Agric. Res., 3(6): 203-210.

2. Monau, P., Raphaka, K., Zvinorova-Chimboza, P. and Gondwe, T. (2020) Sustainable utilization of indigenous goats in Southern Africa. Diversity, 12(1): 20.

3. Henchion, M., Hayes, M., Mullen, A.M., Fenelon, M. and Tiwari, B. (2017) Future protein supply and demand: Strategies and factors influencing a sustainable equilibrium. Foods, 6(7): 53.

4. Ritchie, H. and Roser, M. (2020) Meat and Dairy Production. Available from: https://www.ourworldindata.org/meat-production. Retrieved on 25-Oct-2020.

5. Velusamy, R., Rani, N., Ponnudurai, G. and Anbarasi, P. (2015) Prevalence of intestinal and haemoprotozoan parasites of small ruminants in Tamil Nadu, India. Vet. World, 8(10): 1205-1209.

6. Singh, E., Kaur, P., Singla, L.D. and Bal, M.S. (2017) Prevalence of gastrointestinal parasitism in small ruminants in western zone of Punjab, India. Vet. World., 10(1): 61-66.

7. Mpofu, T.J., Nephawe, K.A. and Mtileni, B.J. (2020) Prevalence of gastrointestinal parasites in communal goats from different agro-ecological zones of South Africa. Vet. World, 13(1): 26-32.

8. Risso, A., Kessler, J.D., Soriano, V.S., Nunes, M.L.A., Machado, G., Langaro, A., Rossetto, R., Zuffo, T., Dallago, M. and Castro, P. (2015) Influence of pathological conditions caused by gastrointestinal parasites infection on pregnant ewe's behavior. Acta Sci. Vet., 43: 1283.

9. Rodríguez, A.V., Goldberg, V., Viotti, H. and Ciappesoni, G. (2015) Early detection of Haemonchus contortus infection in sheep using three different faecal occult blood tests. Open Vet. J., 5(2): 90-97.

10. Jegede, O.C., Adejoh, A.A., Obeta, S.S. and Olayemi, O.D. 
(2015) Gastrointestinal parasites of sheep and goats in Gwagwalada area council, federal capital territory, Abuja, Nigeria; with a special reference to sex, breed and age. Alex. J. Vet. Sci., 46(1): 170-176.

11. Maqbool, I., Wani, Z.A., Shahardar, R.A., Allaie, I.M. and Shah, M.M. (2017) Integrated parasite management with special reference to gastrointestinal nematodes. J. Parasit. Dis., 41(1): 1-8.

12. Erez, M.S. and Kozan, E. (2018) Anthelmintic resistance in farm animals. Kocatepe Vet. J., 11(3): 322-330.

13. Kelley, J.M., Elliott, T.P., Beddoe, T., Anderson, G., Skuce, P. and Spithill, T.W. (2016) Current threat of triclabendazole resistance in Fasciola hepatica. Trends Parasitol., 32(6): 458-469.

14. Woodgate, R.G., Cornell, A.J. and Sangster, N.C. (2017) Occurrence, measurement and clinical perspectives of drug resistance in important parasitic helminths of livestock. In: Mayers, D.L., Sobel, J.D., Ouellette, M., Kaye, K.S. and Marchaim, D., editors. Antimicrobial Drug Resistance. Vol. 2. Springer, Switzerland. p1305-1326.

15. Falowo, A.B. and Akimoladun, O.F. (2019) Veterinary drug residues in meat and meat products: Occurrence, detection and implications. In: Bekoe, S.O., Saravanan, M., Adosraku, R.K. and Ramkumar, P.K., editors. Veterinary Medicine and Pharmaceuticals. IntechOpen, United Kingdom.

16. Tsotetsi, A.M. and Mbati, P.A. (2003) Parasitic helminths of veterinary importance in cattle, sheep and goats on communal farms in the Northeastern free state, South Africa. $J . S$. Afr. Vet. Assoc., 74(2): 45-48.

17. Gwaze, F.R., Chimonyo, M. and Dzama, K. (2009) Communal goat production in Southern Africa: Review. Trop. Anim. Health Prod., 41(7): 1157-1168.

18. Adeyemi, M.T., Morenikeji, O.A., Emikpe, B.O. and Jarikre, T.A. (2017) Interactions between gastrointestinal parasitism and pneumonia in Nigerian goats. J. Parasit. Dis., 41(3): 726-733.

19. Hassan, N.M.F., Farag, T.K., Abu El Ezz, N.M.T. and AbouZeina, H.A.A. (2019) Prevalence assessment of gastrointestinal parasitic infections among goats in Giza Governorate, Egypt. Bull. Natl. Res. Cent., 43: 127.

20. Mohammed, N., Taye, M., Asha, A. and Sheferaw, D. (2016) Epizootological study of small ruminant gastrointestinal strongyles in Gamo-Gofa Zone, Southern Ethiopia. J. Parasit. Dis., 40(2): 469-474.

21. Ntonifor, H., Shei, S., Ndaleh, N. and Mbunkur, G. (2013) Epidemiological studies of gastrointestinal parasitic infections in ruminants in Jakiri, Bui division, North West region of Cameroon. J. Vet. Med. Anim. Health, 5(12): 344-352.

22. Squire, S.A., Robertson, I.D., Yang, R., Ayi, I. and Ryan, U. (2019) Prevalence and risk factors associated with gastrointestinal parasites in ruminant livestock in the Coastal Savannah zone of Ghana. Acta Trop., 199: 105126.

23. Zvinorova, P.I., Halimani, T.E., Muchadeyi, F.C., Matika, O., Riggio, V. and Dzama, K. (2016) Prevalence and risk factors of gastrointestinal parasitic infections in goats in low-input low-output farming systems in Zimbabwe. Small Rumin. Res., 143: 75-83.

24. Ahmed, A., Dar, M.A., Bhat, A.A., Jena, B., Mishra, G.K. and Tiwari, R.P. (2015) Study on haemato-biochemical profile in goats suffering from gastrointestinal parasitism in Jaipur district of Rajasthan. J. Livest. Sci., 6: 52-55.

25. Moudgil, A.D., Sharma, A., Verma, M.S., Kumar, R., Dogra, P.K. and Moudgil, P. (2017) Gastrointestinal parasitic infections in Indian Gaddi (goat) breed bucks: Clinical, hemato-biochemical, parasitological and chemotherapeutic studies. J. Parasit. Dis., 41(4): 1059-1065.

26. Wamboi, P., Waruiru, R.M., Mbuthia, P.G., Nguhiu, J.M. and Bebora, L.C. (2020) Haemato-biochemical changes and prevalence of parasitic infections of indigenous chicken sold in markets of Kiambu county, Kenya. Int. J. Vet. Sci. Med., 8(1): 18-25.

27. Goklaney, D., Singh, A.P., Dhuria, R.K. and Ahuja, A.
(2012) Therapeutic evaluation of mineral preparation for amelioration of anaemia in goats of arid zone of Rajasthan. Iran. J. Appl. Anim. Sci., 2(2): 137-141.

28. Radostitis, O.M., Gay, C.C. and Blood, D.C. (1994) Veterinary Medicine: (A Text Book of Disease of Cattle, Sheep Goats, Pigs and Horses). Saunders W.B, Philadelphia, PA. p304.

29. Kahn, M.C. and Line, S. (2010) Reference guides. The Merck Veterinary Manual, 1:9th $\mathrm{ed}$. Merck and Co., New Jersey, USA. p2584-85.

30. Peters, S.O., Gunn, H.H., Imumorin, I.G., Agaviezor, B.O. and Ikeobi, C.O. (2011) Haematological studies on frizzled and naked neck genotypes of Nigerian native chickens. Trop. Anim. Health Prod., 43(3): 631-638.

31. Al-Bulushi, S., Shawaf, T. and Al-Hasani, A. (2017) Some hematological and biochemical parameters of different goat breeds in the Sultanate of Oman a preliminary study. Vet. World, 10(4): 461-466.

32. Kramer, J.W. (2000) Normal hematology of cattle, sheep and goats. In: Veterinary Hematology. $5^{\text {th }}$ ed. Lippincott Williams \& Wilkins, Philadelphia, PA. p1075-1084.

33. Mohammed, S., Razzaque, M.A., Omar, A., Albert, S. and Al-Gallaf, W. (2016) Biochemical and hematological profile of different breeds of goat maintained under intensive production system. Afr. J. Biotechnol., 15(24): 1253-1257.

34. Isaac, L.J., Abah, G., Akpan, B. and Ekaette, I.U. (2013) Haematological properties of different breeds and sexes of rabbits. In: Proceedings of the 18th Annual Conference of Animal Science Association of Nigeria. Animal Science Association of Nigeria, Abuja, Nigeria. p24-27.

35. Madan, J., Sindhu, S., Gupta, M. and Kumar, S. (2016) Hematobiochemical profile and mineral status in growing Beetal goat kids. J. Cell Tissue Res., 16(1): 5517-5522.

36. El-Mandrawy, S.A.M. and Alam, R.T.M. (2018) Hematological, biochemical and oxidative stress studies of lumpy skin disease virus infection in cattle. J. Appl. Anim. Res., 46(1): 1073-1077.

37. Low, A.B. and Rebelo, A.G. (1996) Vegetation of South Africa, Lesotho and Swaziland. Department of Environmental Affairs and Tourism, Pretoria. Available from: http://www.ngo.grida.no/soesa/nsoer/Data/vegrsa/ vegrastart.htm. Retrieved on 03-02-2014.

38. Schulze, R.E. (1997) South African Atlas of Agrohydrology and Climatology, Report TT82/96. Water Research Commission, Pretoria.

39. Mpofu, T.J., Ginindza, M.M., Siwendu, N.A., Nephawe, K.A. and Mtileni, B.J. (2017) Effect of agro-ecological zone, season of birth and sex on pre-weaning performance of Nguni calves in Limpopo Province, South Africa. Trop. Anim. Health Prod., 49(1): 187-194.

40. United Nations, Environmental Management Group. (2011) Progress Report. Global Drylands: A United Nations Systemwide Response, GE.11-70003. Available from: https://www.unccd.int/sites/default/files/sessions/ documents/ICCD_CRIC9 1/CRP1eng.pdf. Retrieved on 13-10-2019.

41. Thrusfield, M. (1997) Veterinary Epidemiology. $2^{\text {nd }}$ ed. Blackwell Sciences, Oxford. p182.

42. Kheirandish, R., Nourollahi-Fard, S.R. and Yadegari, Z. (2014) Prevalence and pathology of coccidiosis in goats in southeastern Iran. J. Parasit. Dis., 38(1): 27-31.

43. Hansen, J. and Perry, B. (1994) Epidemiology, Diagnosis and Control of Helminth Parasites of Ruminants. $2^{\text {nd }}$ ed. ILRAD, Nairobi, Kenya. p158-168.

44. Aumont, G., Gruner, L. and Hostache, G. (2003) Comparison of the resistance to sympatric and allopatric isolates of Haemomchus contrortus of black belly sheep in Guadeloupe (FWI) and INRA 401 sheep in France. Vet. Parasitol., 116(2): 139-150.

45. Foriet, W.(1999) Reference Manual of Veterinary Parasitology. $5^{\text {th }}$ ed. Wiley Blackwell, New York, USA. p22-26.

46. Zajac, M. and Conboy, G. (2006) Veterinary Clinical 
Parasitology. $7^{\text {th }}$ ed. Black Well Publishing Company, United Kingdom.

47. Van Wyk, J.A., Cabaret, J. and Michael, L.M. (2004) Morphological identification of nematodes of small ruminants and cattle simplified. Vet. Parasitol., 119(4): 277-306.

48. Minitab 17 Statistical Software. (2017) Computer Software. Minitab, Inc., State College, PA.

49. Cattadori, I.M., Boag, B. and Hudson, P.J. (2008) Parasite co-infection and interaction as drivers of host heterogeneity. Int. J. Parasitol., 38(3-4): 371-380.

50. Turgeon, G., Kutz, S.J., Lejeune, M., St-Laurent, M.H. and Pelletier, F. (2018) Parasite prevalence, infection intensity and richness in an endangered population, the AtlanticGaspésie caribou. Int. J. Parasitol. Parasites Wildl., 7(1): 90-94.

51. Bush, A.O., Lafferty, K.D., Lotz, J.M. and Shostak, A.W. (1997) Parasitology meets ecology on its own terms: Margolis et al. revisited. J. Parasitol., 83(4): 575-583.

52. Brockus, C.W. (2011) Erythrocytes. In: Latimer, K.S., editor. Duncan and Prasse's Veterinary Laboratory Medicine: Clinical Pathology. $5^{\text {th }}$ ed. Wiley, Chichester, UK. p3-44.

53. Kraft, W. and Dürr, U.M. (2005) Klinische labordiagnostik in der tiermedizin. In: Clinical Laboratory Diagnostics in Veterinary Medicine. $6^{\text {th }}$ ed. Schattauer, Stuttgart, Germany.

54. Menkir, M.S., Uggla, A. and Waller, P.J. (2006) Epidemiology and seasonal dynamics of gastrointestinal nematode infections of sheep in a semi-arid region of eastern Ethiopia. Vet. Parasitol., 143(3-4): 311-321.

55. Dabasa, G., Shanko, T., Zewdei, W., Jilo, K., Gurmesa, G. and Abdela, N. (2017) Prevalence of small ruminant gastrointestinal parasites infections and associated risk factors in selected districts of Bale zone, South Eastern Ethiopia. J. Parasitol. Vector Biol., 9(6): 81-88.

56. Hunters, R.A. and Buck, N. (1992) Nutrition and climatic limits of beef production in the tropics. In: Jarrige, R. and Beranger, C., editors. World Animal Science, C5. Beef Cattle Production. Elsevier Science Publisher, Netherlands. p379-387.

57. Verma, R., Sharma, D., Paul, S., Kumaresan, G., Dige, M., Kumar, S.V., Kumar, R.P., Bhusan, S. and Banerjee, S.P. (2018) Epidemiology of common gastrointestinal parasitic infections in goats reared in semi-arid region of India. J. Anim. Res., 8(1): 39-45.

58. Qamar, M.F. (2009) Epidemiology, Sero-diagnosis, Economic Losses and Control of Haemonchosis in Sheep and Goats, Ph.D. Thesis. Department of Parasitology, University of Veterinary and Animal Science, Lahore, Pakistan. p63-113.

59. Babar, M.E., Hussain, T., Ahmad, M.S., Ali, A., Abbas, K., Ali, M.M. (2015) Evaluation of Pakistani goat breeds for genetic resistance to Haemonchus contortus. Acta Vet. Brno, 84(3): 231-235.

60. Onzima, R.B., Mukiibi, R., Ampaire, A., Benda, K.K. and
Kanis, E. (2017) Between-breed variations in resistance/ resilience to gastrointestinal nematodes among indigenous goat breeds in Uganda. Trop. Anim. Health Prod., 49(8): 1763-1769.

61. Rouatbi, M., Gharbi, M., Rjeibi, M.R., Ben Salem, I., Akkari, H., Lassoued, N. and Rekik, M. (2016) Effect of the infection with the nematode Haemonchus contortus (Strongylida: Trichostrongylidae) on the haematological, biochemical, clinical and reproductive traits in rams. Onderstepoort J. Vet. Res., 83(1): 1-8.

62. Arfuso, F., Fazio, F., Rizzo, M., Marafioti, S., Zanghì, E. and Piccione, G. (2016) Factors affecting the hematological parameters in different goat breeds from Italy. Ann. Anim. Sci., 16(3): 743-757.

63. Rathwa, S.D., Vasava, A.A., Pathan, M.M., Madhira, S.P., Patel, Y.G. and Pande, A.M. (2017) Effect of season on physiological, biochemical, hormonal, and oxidative stress parameters of indigenous sheep. Vet. World, 10(6): 650-654.

64. Ribeiro, M.N., Ribeiro N.L., Bozzi, R. and Costa, R.G. (2018) Physiological and biochemical blood variables of goats subjected to heat stress-a review. J. Appl. Anim. Res., 46(1):1036-1041.

65. Sharma, D.K., Agrawal, N., Mandal, A., Nigam, P. and Bhushan, S. (2009) Coccidia and gastrointestinal nematode infections in semi-intensively managed Jakhrana goats of semi-arid region of India. Trop. Subtrop. Agroecosyst., 11(1): 135-139.

66. Ayaz, M.M., Raza, M.A., Murtaza, S. and Akhtar, S. (2013) Epidemiological survey of helminths of goats in Southern Punjab, Pakistan. Trop. Biomed., 30(1): 62-71.

67. Asanji, M.F. and Williams, M. (1987) Variables affecting the population dynamics of gastrointestinal helminth parasites of small ruminants in Sierra Leone. Bull. Anim. Health Prod., 35(40): 3087-3113.

68. Shah-Fischer, M. and Say, R. (1989) Manual of Tropical Veterinary Parasitology. CAB International, The Technical Center for Agricultural and Rural Cooperation (CTA), United Kingdom.

69. Daramola, J.O., Adeloye, A.A., Fatoba, T.A. and Soladoye, A.O. (2005) Haematological and biochemical parameters of West African Dwarf goats. Livestock Research for Rural Development. Available from: http:// www.lrrd.org/lrrd17/8/dara17095.htm. Retrieved on 22-01-2014.

70. Singh, A.K., Das, G., Roy, B., Nath, S., Naresh, R. and Kumar, S. (2015) Prevalence of gastro-intestinal parasitic infections in goat of Madhya Pradesh, India. J. Parasit. Dis., 39(4): 716-719.

71. Audu, Y., Lekko, Y.M., Umar, M.B., Mshellia, E.S. and Mana, H.P. (2018) Effect of strongyle on haematological parameters of cattle in Maiduguri, Borno state, Nigeria. J. Agric. Vet. Sci., 11(1): 60-63. 